\title{
Analysis of Quality of Backyard Compost and Its Potential Utilization as a Circular Bio-Waste Source
}

\author{
Apolka Ujj 1밀 Kinga Percsi ${ }^{1, *}$, Andras Beres ${ }^{2}$, Laszlo Aleksza ${ }^{2}$, Fernanda Ramos Diaz ${ }^{3, *}$, Csaba Gyuricza ${ }^{4}$ \\ and Csaba Fogarassy $1, *$ (D)
}

1 Institute of Sustainable Development and Farming, Hungarian University of Agriculture and Life Sciences (MATE), Pater Karoly Street-1, 2100 Gödöllő, Hungary; ujj.apolka@uni-mate.hu

2 Institute of Environmental Sciences, Hungarian University of Agriculture and Life Sciences (MATE), Pater Karoly Street-1, 2100 Gödöllő, Hungary; beres.andras@uni-mate.hu (A.B.); aleksza.laszlo@uni-mate.hu (L.A.)

3 Doctoral School of Economics and Regional Sciences, Hungarian University of Agriculture and Life Sciences (MATE), Pater Karoly Street-1, 2100 Gödöllő, Hungary

4 Institute of Agronomy, Hungarian University of Agriculture and Life Sciences (MATE), Pater Karoly Street-1, 2100 Gödöllő, Hungary; gyuricza.csaba@uni-mate.hu

* Correspondence: percsi.kinga@uni-mate.hu (K.P.); Maria.Fernanda.Ramos.Diaz@hallgato.uni-szie.hu (F.R.D.); fogarassy.csaba@uni-mate.hu (C.F.)

Citation: Ujj, A.; Percsi, K.; Beres, A.; Aleksza, L.; Diaz, F.R.; Gyuricza, C.; Fogarassy, C. Analysis of Quality of Backyard Compost and Its Potential Utilization as a Circular Bio-Waste Source. Appl. Sci. 2021, 11, 4392. https://doi.org/10.3390/app11104392

Academic Editor: Carlos Rico de la Hera

Received: 13 April 2021

Accepted: 6 May 2021

Published: 12 May 2021

Publisher's Note: MDPI stays neutral with regard to jurisdictional claims in published maps and institutional affiliations.

Copyright: (c) 2021 by the authors. Licensee MDPI, Basel, Switzerland. This article is an open access article distributed under the terms and conditions of the Creative Commons Attribution (CC BY) license (https:// creativecommons.org/licenses/by/ $4.0 /)$.

\begin{abstract}
The use and quality analysis of household compost have become very important issues in recent years due to the increasing interest in local food production and safe, self-produced food. The phenomenon was further exacerbated by the COVID-19 pandemic quarantine period, which gave new impetus to the growth of small home gardens. However, the knowledge associated with making high-quality compost is often lacking in home gardeners. Therefore, the objective of this research was to find answers to the following questions: can the quality of backyard compost be considered safe in terms of toxicity and nutrient content? Can weed seed dispersion affect the usability of backyard compost? In general, can the circulation of organic matter be increased with the spread of home composting? In this study, 16 different house composts were analysed for stability, weed seed contamination, toxic elements, and nutrient content using analysis of variance. The results of the research showed that the quality properties of the composts (including their weed seed dispersion effect) were greatly influenced by the different techniques and raw materials used. The toxicity levels, as well as the content of macro and microelements, were within the parameters of safe-quality compost. The specific macronutrient $(\mathrm{Ca}, \mathrm{Mg})$ and micronutrient $(\mathrm{Fe}, \mathrm{Mn})$ contents of the tested composts have a similar and, in some cases, more favorable nutrient supply capacity in crop production than the frequently-used cow manure-based composts. With a plan of basic education on composting, there is potential to encourage farmyard composting.
\end{abstract}

Keywords: compost quality; backyard compost; toxins; nutrient; oxygen consumption; AT4 value; weed control; hygienisation; compost stability; waste circulation

\section{Introduction}

The growing popularity of the concept of circular economy gives favorable background support to environmentally friendly waste-management solutions. It is different from any of the policies of the European Union; therefore, it is worth treating as a special phenomenon. Its main goal is to manage waste through the circular design of material use, product use, and system applications [1]. However, positive tendencies can be observed in the sorting of biowaste due to the principles of circular economy and the assumptions of the zero waste program [2]. The majority of this biowaste is not collected selectively or utilized, but collected together with the municipal solid waste and placed in waste disposal sites or waste incinerators [3]. Thus, the nutrient contents of these biowastes, which could be used in agriculture, are lost and, in most cases, are replaced by fertilizers which can 
have negative long-term effects on the soil and the environment [4]. Furthermore, these solutions unnecessarily decrease the available waste disposal capacity and increase the environmental risks of waste incineration and waste disposal [5].

Composting is a safe method of waste management [6] and has the potential to improve soil structure, texture, and aeration, as well as improve the water retention capacity of the soil [7]. In addition, the Environmental Protection Agency (EPA) of the United States declared that composting reduces methane emissions in landfills, lowering their carbon footprint [8]. Therefore, composting is an environmentally friendly alternative applied to recycle organic waste and obtain products used as amendments in agriculture [9-14]. Organic fertilizers are originated from agricultural by-products (manures, liquid manures, straw, plant residues, etc.), residues and waste from the food industry (e.g., sewage, waste from slaughterhouses, etc.), and biologically degradable municipal waste [4,15-17]. By selective collection and composting of these biowastes, separated from the municipal solid wastes, it is possible to obtain valuable, secondary raw materials that can be utilized locally, in gardens, and are produced in an economically feasible way.

\subsection{Backyard Composting Methods}

Backyard composting cannot be considered as a uniform method since the ingredients of the compost, the applied technical solutions (composting drums or bins, composting tanks, nets, or prisms), and the treatment of the materials (grinding, turning, aeration) differ considerably $[17,18]$. It is important to emphasize that backyard composting is considered as a closed system as the used raw materials are created, processed, and utilized on-site by the compost maker themselves [19]. Hence, the available information regarding the quality of backyard composts is limited, occasional, and based on a small number of samples. However, there are numerous available studies regarding industrial composting [20-23]. In Hungary, there has not been any such comprehensive examination carried out related to backyard composts. The novelty of the current research is that we did not find any similar research in the literature, because the method of backyard composting differs from household to household and the technological descriptions cannot be followed in practice; conducting scientific research in the field is, therefore, a very difficult task. Consequently, there is limited information about the quality and physical, chemical, and biological parameters of backyard compost.

\subsection{Determination of Compost Quality and ITS Measurement}

According to Frickte [24], the quality of compost is mainly determined by the kind and composition of input materials, the degree of purity and quality of soil, and emissions in the specific area of collection. He also highlighted that compost quality is substantially influenced by the type of technology applied during the composting process. However, his findings related to the importance of treatments during the composting were not substantiated by Jakubus's [25] examination. The determination and evaluation of compost quality can be carried out by examining physical (e.g., color, odor), chemical (e.g., C/N ratio, nitrification), and microbiological parameters (e.g., self-heating test, respiration), and parameters that influence its effect on the grown crops (e.g., germination test) [26]. Considering the abovementioned, in the case of the quality of backyard compost, these parameters are advisable to examine and are determinant during backyard compost use. The parameters are as follows: maturity and stability, which has a direct effect on plant development; macro and micronutrient contents, which contribute to the nutrient replenishment; toxic element contents, which determine the safe use of composts; and the weed seed content, which influences the long-term weeding effect of backyard composts and as such is a very practical quality parameter. Maturity can be characterized by physical, chemical, and biological stability [27]. Stability refers to the microbial activity in compost, and is evaluated by respirometric measurements or by analysis of the changes in chemical properties [28]. Furthermore, stability can be evaluated by using biological methods such as the germination index (GI) [29-31]. It should be noted that the principle of microbiological 
maturity tests depends on the assumptions that the maturity of composts is strongly related to stability, and that the microbial activity of composts determines their maturity [32,33]. The different maturity levels of composts depend on the alteration of the different components, the extent and quality of humification and mineralization processes, and the degree of decomposition of the original organic materials [34].The examination of the respiration of composts is an adequate method that can be applied as a test for microbiological compost maturity [26]. The respiration examination can measure either the carbon dioxide evolution or the consumed oxygen during the biological decomposition of the compost samples. Several studies considered oxygen consumption as a reliable variable for evaluating the development of composting due to its correlation with the metabolic potential of compost $[6,35,36]$. Additionally, oxygen is directly responsible for the oxidation of organic matter [8]. This can be measured through respirometry, a recognized method for measuring the oxygen consumption of microorganisms [37]. In the case of this technique, two methods can be differentiated, i.e., the static and the dynamic methods. The differentiation depends on the whether the measurements are carried out with or without a continuous oxygen supply $[35,38,39]$. The so-called $\mathrm{AT}_{4}$ value is an internationally accepted method to determine the maturity, stability, and usability of composts. It measures the total amount of oxygen that is consumed by the microorganisms during the biological decompositions of the biologically degradable organic matter contained in the samples within four days of examination (examined parameter: respiration activity, oxygen demand, unit: $\mathrm{mg} \mathrm{O}_{2} / g$ dry matter) [39-41].

\subsection{Macro and Micro Nutrient Content of Compost}

Jakubus [25] examined the chemical composition of different compost samples and found that the differences in the chemical composition of composts primarily resulted from the raw materials used in composting, and to a lesser extent from the processes and technology used. One of the important results of the abovementioned examination was that compost with low nutrient and organic matter content could be characterized by favorable stability and maturity parameters, as organic matter content decreases during composting. In addition, the author found that the composts based on yard trimmings and household wastes prepared in home composters, while highly-recommended for small-scale vegetable cultivation, had less desirable chemical composition compared with composts prepared with a share of sewage sludge, whilst the mixture of municipal sewage sludge and biowastes is recommended to build soil production capacity.

\subsection{Toxicity Levels and Chemical Impact of Compost}

Another important quality aspect of the compost is the chemical and environmental impact caused by the application. The pollution caused by potentially toxic elements (PTEs) (e.g., Sb, As, Cd, Cr, Cu, Pb, Hg, Ni, Se, Ag, Sn, Zn) have particularly relevant ecological and human health issues. Potentially toxic elements (PTEs) are a major concern from food safety, environmental, and ecological points of view [42]. There is a worldwide increase in heavy metal or potentially toxic element (PTE) contamination in agricultural soils caused mainly by human and industrial action, which leads to food contamination through crops [43]. Toxic elements, especially the heavy metals of the periodic table, are normal elements found in the environment, and trace amounts of them are always found in foodstuffs [44]; however, foods from contaminated areas may contain higher amounts. Toxic elements primarily enter foodstuffs through contact with the environment. Cadmium is one of the most mobile elements among all toxic heavy metals. Because of its high mobility, cadmium is readily taken up by plants from the soil and transferred to the aerial parts of the plant, where it can accumulate to a high level. Because of its high mobility in soil, the bioaccumulation of cadmium in plant-based food is usually high compared with the other trace elements $[45,46]$. Organic amendments can contain undesirable components, such as potentially toxic elements, that affect both humans and the environment. PTEs (and several chemical compounds) can also affect soil microbial communities and, in turn, 
soil functionality and fertility [47]. The soil, by itself, is not able to biodegrade the heavy metals, which have the tendency to persist and accumulate. It is therefore necessary for the assessment of the parameters of the quality of compost to consider both the aspects connected to agronomic efficiency and those of environmental compatibility [48].

\subsection{Weed-Seed Dispersal Effect and Biological Quality}

During quality analysis of compost, the weed seed dispersal effect is an important biological qualitative parameter to consider [49]. In the case of application in the field of a compost containing a significant amount of viable weed seeds and plant propagules, the emerging weeds can cause significant damage to the crop in terms of quality and yield. These disadvantageous effects can be reduced or even completely eliminated by properly performed composting. Studies addressing these issues showed that inappropriate composting practices, specifically related to short composting time and to a lesser extent to temperature, result in weed seeds not losing their viability by the end of the composting process [50]. The survival of weed seeds and viable plant propagules depends on different processes taking place during composting and the characteristics of resistance of each weed variety. The most important parameters to consider are the following: length of time at the appropriate temperature within the active phase of composting, and moisture content. Based on the experimental results, the different weed species lose their viability at different temperatures and periods of time [51]. The fate of weed seeds is influenced considerably by the moisture content as well: higher moisture content causes certain weed seeds to lose their viability at a higher rate $[52,53]$. According to the parameters mentioned above, certain weeds, such as Solanum nigrum L. [51], Sorghum halepense (L.) Pers., and Convolvulus arvensis L. are considered very resistant [54]. Strict regulations have been established in the compost-related national regulations and standards to ensure the appropriate sterility of the produced composts and to eliminate the viability of the weed seeds. The temperature that needs to be achieved in the active phase of the composting process and the related time period are also set strictly in these regulations. In addition, these regulations are not unified in Europe; they can differ in the expected highest temperature and the time interval as well. In Austria, for example, $55-65{ }^{\circ} \mathrm{C}$ has to be maintained for 14 days; in Germany or Denmark, at least $55^{\circ} \mathrm{C}$ has to be maintained for 14 days. In France, at least $60{ }^{\circ} \mathrm{C}$ has to be maintained for 4 days [49]. However, the determination of the number of weed plants (on a weight or volume basis) that emerge from an appropriately prepared and properly produced compost sample is a common feature of the currently available standard methods for the examination of the weed seed dispersal effect of composts.

On the whole, it is important to examine the quality of the composts that are utilized in farming or household gardening to ensure quality, even if they are only used in small quantities.

This research analyzed the potential that backyard composting offers as an alternative to remove some of the pressure that biowaste has on traditional waste-management systems and its potential usability at a household level.

In order to determine the quality and potential utilization of backyard compost, this research intends to answer the following questions:

Is the quality of backyard compost, in terms of toxicity and nutrient content, considered safe to use at a household and farm level? Do the different treatments and ingredients (raw materials) applied in the composting process have a significant impact on the quality of the final product? Are the techniques and treatments used in individual backyard composting adequate enough for agricultural purposes, or should the raw materials be collected by an external organization and delivered to a common composting site for stricter control and unified quality? Could weed seed dispersion affect the usability of backyard compost? Do the values and species identified in the weed seed dispersion effect evaluation fall within the acceptable parameters at a household and farm level? Is backyard composting a feasible circular alternative to conventional waste management and environmental issues? 
According to the objectives abovementioned, the research hypothesis is that, based on the complex qualitative analysis of backyard composting, it is highly recommended to use composting in backyard gardening because the quality level reaches the level defined by the related regulations and national norms.

\section{Materials and Methods}

\subsection{The Examined Composts Materials}

The samples of this research had two distinctive origins: backyard compost at a household level and at an ecological farm level. In higher proportion, we examined composts that were mainly produced in gardens of family houses by utilizing biowaste products as main ingredients. The ecological farms, from which three of the examined compost samples originated, are predominantly characterized by the production of vegetables, herbs, and fruits. The samples produced therein contained walnut leaves, bean stems, plant waste, and horse manure as main ingredients. The raw materials, the technology of composting, and the age of the produced composts varied considerably from one sample to another. It is necessary to highlight that all the factors mentioned above were decided by the compost makers themselves and were not subject to our interference. The composts included in the examinations were considered mature and ready for application by the compost producers in all cases. The most important characteristics of the samples used for this research are summarized in Table 1.

Table 1. The properties of the examined composts (BYC—backyard compost; ECOL-ecological farm).

\begin{tabular}{|c|c|c|c|c|c|c|}
\hline Code & Type & Method of Composting & Raw Materials & Preparation & Treatment & Age \\
\hline $\mathrm{A}$ & BYC & Pile & Garden green waste & Grinding & Monthly turning & 2 years \\
\hline B & BYC & Pile & Garden green waste & Grinding & Monthly turning & 1 year \\
\hline $\mathrm{C}$ & BYC & Closed composting bin & Garden green waste, kitchen waste & Grinding & $\begin{array}{l}\text { Monthly turning, } \\
\text { moistening }\end{array}$ & 2 years \\
\hline $\mathrm{D}$ & BYC & Open composting & Garden green waste, kitchen waste & Grinding & $\begin{array}{l}\text { Monthly turning, } \\
\text { moistening }\end{array}$ & 1.5 years \\
\hline $\mathrm{E}$ & BYC & Open composting & $\begin{array}{l}\text { Garden green waste, wood ash, } \\
\text { poultry manure, soil }\end{array}$ & - & - & 3 years \\
\hline $\mathrm{F}$ & BYC & Open composting & Garden green waste, wood ash, soil & - & - & 3 years \\
\hline G & BYC & Open composting & Garden green waste, kitchen waste & Grinding & Addition of earthworms & 3 years \\
\hline $\mathrm{H}$ & BYC & Pile & $\begin{array}{l}\text { Garden green waste, kitchen waste, } \\
\text { rabbit manure }\end{array}$ & Grinding & Monthly turning & 2 years \\
\hline I & BYC & Open composting & $\begin{array}{l}\text { Garden green waste, kitchen waste, } \\
\text { wood ash }\end{array}$ & - & $\begin{array}{l}\text { Periodic turning, } \\
\text { addition of earthworms }\end{array}$ & 2 years \\
\hline $\mathrm{J}$ & BYC & Open composting & Garden green waste & Grinding & Addition of earthworms & 2 years \\
\hline K & BYC & Pile & $\begin{array}{l}\text { Garden green waste, grape leaves, } \\
\text { dishwashing water }\end{array}$ & Grinding & - & 4 years \\
\hline $\mathrm{L}$ & BYC & Pile & $\begin{array}{l}\text { Garden green waste, sycamore leaves, } \\
\text { poultry manure }\end{array}$ & Grinding & - & 4 years \\
\hline M & BYC & Open composting & Garden green waste, fruit waste & - & Addition of earthworms & 4 years \\
\hline $\mathrm{N}$ & ECOL & Open composting & Walnut leaves, bean stem (50-50\%) & & $\begin{array}{l}\text { Periodic turning, } \\
\text { moistening }\end{array}$ & 8 months \\
\hline $\mathrm{O}$ & ECOL & Open composting & Walnut leaves & & $\begin{array}{l}\text { Periodic turning, } \\
\text { moistening }\end{array}$ & 8 months \\
\hline$P$ & ECOL & Open composting & $\begin{array}{l}\text { Horse manure and other plant } \\
\text { materials }(80-20 \%)\end{array}$ & & $\begin{array}{l}\text { Periodic turning, } \\
\text { moistening }\end{array}$ & 1.5 years \\
\hline
\end{tabular}

\subsection{Methods}

Compost samples were collected from home-mixed composts that were considered mature, stable, and ready for use by their producer. The representative samples, which consisted of the mixture of several subsamples, were taken from different parts of the 
compost piles and weighed 10-30 kg. The samples were stored in a refrigerator or in a deep freezer until the laboratory examinations started. During preparation, the samples were chopped into $10 \mathrm{~mm}$ in size with a shredder and were sent through a $10 \mathrm{~mm}$ sieve. The samples were prepared by sample quartering from the whole samples for the examinations. The experiments were carried out in the Waste Management Laboratory, Institute of Environmental Sciences at MATE, formerly Szent István University.

\subsubsection{Stability Measurement}

In order to measure the stability, the $\mathrm{AT}_{4}$ respiration activity of the examined compost samples was determined based on the method written in ÖNORM S 2027-4:2012 standard [55]. The moisture content of the examined samples was set by hand-squeeze test; thus, the moisture content was between $45 \%$ and $55 \%$. The moisture content of the samples was determined according to the MSZE 21420-18:2005 standard [56]. The biological activity (stability) of the compost samples was determined by measuring the respiration activity and by determining the $\mathrm{AT}_{4}$ values of the samples in three replicates according to the applied standard. The $\mathrm{AT}_{4}$ respiration activity values were determined by OxiTop Control measuring system. We placed a $100 \mathrm{~cm}^{3}$ prepared, moistened sample in the vessels. During the determination of oxygen consumption, according to the description, the vessels were placed in a thermostat cabinet, and $20{ }^{\circ} \mathrm{C}$ was maintained during the experiment. During the measurements, the samples placed in aerobic conditions in the vessels started to biologically decompose depending on their biological activity (stability). During this decomposition process, the oxygen in the vessel was partly consumed and its quantity decreased. The carbon dioxide that was produced during the aerobic biological decomposition of the samples was absorbed in the air of the vessel by an absorber, which resulted in a decrease in air pressure in the vessel that was then in proportion with the oxygen consumption and the respiration activity. A measuring device (controller) was part of the measuring system, by which the basic parameters of the samples and the measurement itself could be set (e.g., volume of the sample, measuring time, air pressure, etc.) in the beginning of the measurements. The measured data could be stored and read in the measuring heads or downloaded to the computer. The $\mathrm{AT}_{4}$ respiration activity values were determined on the dry-matter basis of the samples ( $\mathrm{mg} \mathrm{O}_{2} / g$ dry matter) using the primer measuring results downloaded from the measuring heads, applying the method written in the standard (average value and standard deviation of the three repetitions). During the examinations, the so-called lag-phase was not noticed in any of the examined samples [57].

\subsubsection{Weed Seed Contamination Effects Determination}

The weed seed dispersion effect of the samples was determined according to the method written in the MSZ-08-0012/4-79 standard (physical, chemical, and biological testing of peat and peat products, examination of weed expansion and germ killing effect) [58]. Based on that standard, we prepared a mixture of compost (with its original moisture content) and soil (Arenosol with 1.6-1.9\% humus content, $\mathrm{pH}$ 6.5-7.5, $\mathrm{CaCO}_{3}$ content is maximum 1\%) in a 1:3 ratio by weight. From this mixture, a similar number of samples (3-3 samples) were measured into plastic containers ( $15 \mathrm{~cm}$ in diameter). The height of the samples was approximately $20 \mathrm{~mm}$ in the containers. Based on the ratio of the weighted mixtures, the weight of the compost and the soil was determined in the plastic containers. In three containers, the same amount of soil (control samples) was measured in three containers in order to examine the weed seed dispersal effect of the soil itself. The mixtures were moistened and kept in a well-lit place at room temperature for 14 days. The evaporated water was replaced daily by measuring the weight loss of the samples. After 14 days, the number of emerged weeds was counted in all the different containers. Then, the number of weeds emerged in the soil samples was subtracted (control samples) from the number of weeds in the compost mixture. The result was determined to be $100 \mathrm{~g}$ of compost material. According to the standard, the number of couch grass (Agropyron repens (L.) P. B.) was determined separately, on the basis of $100 \mathrm{~g}$ of compost. 


\subsubsection{Toxic Elements and Nutrient Contents Analysis}

The sampling, storing, preparation, grinding, and sample quartering of the composts were carried out by the previously described method. For the examination of the potentially toxic element $(\mathrm{Cd}, \mathrm{Cr}, \mathrm{Cu}, \mathrm{Hg}, \mathrm{Ni}, \mathrm{Pb}, \mathrm{Zn})$ and macro and micronutrient content, $500 \mathrm{~g}$ of subsample was air dried in the laboratory. All unsuitable substances (glass, metal, plastic, gravel, etc.) were removed from the samples, and all the compost samples were then chopped into less than $0.25 \mathrm{~mm}$ in size by a shredder and homogenized. The samples for the examinations $(0.25-0.5 \mathrm{~g})$ were further prepared by sample quartering from the whole, homogenized, $<0.25 \mathrm{~mm}$ sized samples for the examinations. The digestion of the samples was carried out by a CEM MARS 5 (CEM Microwave Corporation, Matthews, $\mathrm{NC}$, USA) microwave digester by applying a mixture of $5 \mathrm{~mL} 65 \mathrm{~m} / \mathrm{m} \% \mathrm{HNO}_{3}$ and $2 \mathrm{~mL}$ $30 \mathrm{~m} / \mathrm{m} \% \mathrm{H}_{2} \mathrm{O}_{2}$. The examination of the samples was carried out by HORIBA JOBIN YVON ACTIVA-M ICP-OES (Horiba Jobin Yvon, Bernsheim, Germany). The moisture content of the samples was determined according to the MSZE 21420-18:2005 standard in a drying oven (Characterization of wastes. Part 18: Determination of humidity and dry matter content).

\subsubsection{Statistical Factor Analysis}

The effects of the different factors, such as methods (pile, closed bin, open composting), treatments (turning, moistening, adding earthworms), type of the samples (backyard, ecological), composting periods, and raw materials were subjected to evaluation with the assistance of one-way ANOVA. Each of the factors was tested independently using the F-test at the significance level $\alpha=0.95$. The dependent variables were the AT4 values and the effects of the similar factors were tested also on the weed seed content, potentially toxic elements, and macro and micro nutrient contents of the different samples. The null hypothesis that the average values of the examined parameter would be equal for each of the 16 composts was tested against the alternative hypothesis stating that not all averages are equal. Scheffe's analysis was also performed, wherein it was possible to distinguish homogeneous groups among the 16 composts. The data were analysed using the SPSS 25 software.

\section{Results}

The age of the examined composts differed considerably; they were between 8 months and 4 years old. The reason why such aged composts were chosen is that backyard composting is a slower process than controlled large-scale composting. Fresh compost can be created in 3 months, but mature composting often takes 12 months (depending on the composting treatments such as turning, wetting, etc.) Compost makers judge the maturity of composts primarily on the basis of physical properties whilst biological properties are not typically taken into account [59]. Accordingly, compost samples were collected for analysis according to two aspects. The first is that the compost sample age exceeded 9 weeks, regardless of any treatments, as the experiment's results suggested that this is the minimum time required for the compost to become stable and to provide a potential $\mathrm{N}$ source [60]. The other aspect is that the compost producer considered the compost samples mature and ready for application based on their own knowledge of composting.

Thus, the different composting periods can be the explanation for the producers having different experiences in practice; they had different knowledge regarding composting and the method thereof (the type of composting device where the process occurred, preparation and the treatment of the raw materials during composting) $[17,59]$. The composts that originated from ecological farms had shorter composting periods (0.8-1.5 years), which can be attributed to the expertise and proper knowledge of long-term farmers. 


\subsection{Compost Maturity}

The results regarding the maturity of the examined composts, the determined $\mathrm{AT}_{4}$ respiration activity values, are shown in Figure 1, on which the determined respiration activity $\left(\mathrm{AT}_{4}\right)$ is recorded.

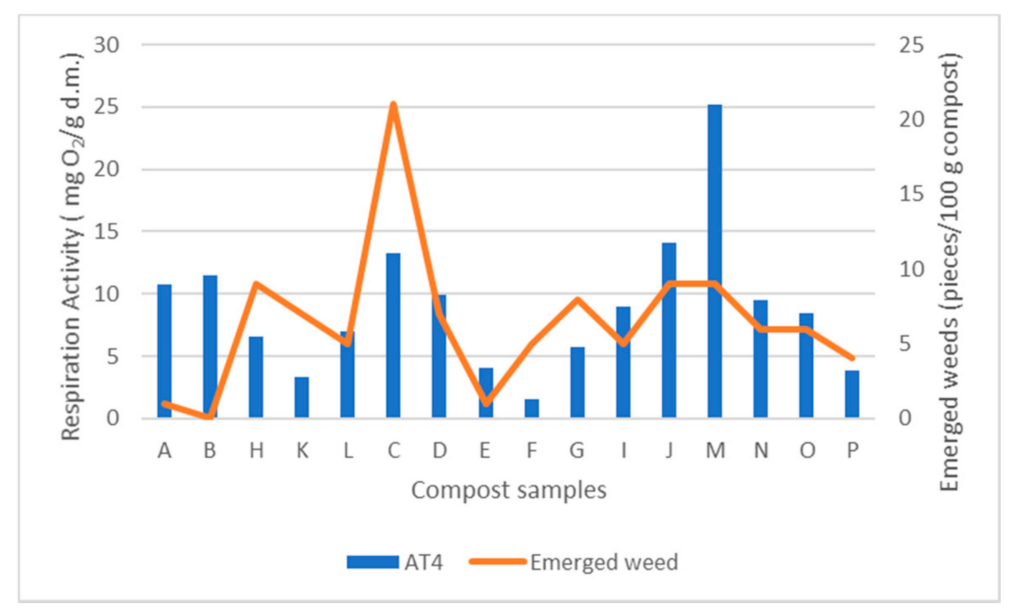

Figure 1. The determined respiration activity (AT4) and the number of weeds that emerged within 14 days.

Based on the determined respiration activity values (AT4), it can be stated that the biological stability of the examined backyard composts that can be determined based on the AT4 values differed considerably (1.6-25.2 $\mathrm{mg} \mathrm{O}_{2} / g$ dry matter). In one case (compost " $\mathrm{M}$ "), the determined respiration activity (AT4) was extremely high (25.2 $\mathrm{mg} \mathrm{O}_{2} / g$ d.m.) There were smaller differences and lower typical ranges experienced in respiration activity in the case of the composts which originated from the ecological farms (3.9-9.5 mg $\mathrm{O}_{2} / g$ d.m.) This difference in the determined biological stability values between the backyard and the ecological composts can be attributed to the fact that the producers in the ecological farms are highly aware of the environmental effects of composting and have more scientific background in the topic. There is no unified regulation in Europe regarding the stability and maturity of the treated biowaste products. In Austria and Germany, in order to determine stability, the extent of respiration activity (AT4) is taken into consideration.

For accomplishing the proper stability, the respiration activity value (AT4) has to decrease below $5 \mathrm{mg} \mathrm{O}_{2} / \mathrm{g}$ d.m. The suggested limit value in the EU for the same parameter is $10 \mathrm{mg} \mathrm{O}_{2} / \mathrm{g} \mathrm{d} . \mathrm{m}$. [23]. If we consider the Austrian and the German qualification aspects among all the examined composts, three backyard composts (E, F, and $\mathrm{K}$ composts) and only one ecological compost $(\mathrm{P})$ met the requirements for the compost maturity. However, based on the suggested, more permissive unified EU limit value, most of the examined backyard composts (8 out of the examined 13 composts) and all of the examined ecological composts show appropriate maturity and stability values. Some backyard composts (A, $\mathrm{B}, \mathrm{C}, \mathrm{J}$, and M), however, still did not meet the requirements even in the case of the less strict limit and showed inappropriate biological stability. In the case of these composts, the beneficial effects of composts on the soils and the soil-plant system notwithstanding, unfavorable effects can also occur due to their inappropriate biological stability. The results obtained regarding the low stability of backyard composts might reinforce the concern about its quality $[17,23,59,60]$. It has to be emphasized that several methods are used worldwide to determine the maturity, biological stability, and the respiration activity of composts. These are the following: the Solvita test, the self-heating test, static respirometry index (SRI), dynamic respiration index (DRI), and the specific oxygen uptake rate (SOUR). The comparability of the results obtained by these different methods has been examined by several authors; as a result, correlations are available to help in the comparison of the available results $[23,38,61]$. 


\subsection{Weed Seed Dispersion}

The experiment carried out on the weed seed dispersion effect of the compost samples is shown in Figure 1, wherein the number of weeds that emerged within 14 days from the compost samples is recorded (calculated to $100 \mathrm{~g}$ of compost). During the 14 days of examination, the following plants emerged from the samples that we could identify at a species level: Solanum lycopersicum L., Amaranthus retroflexus L., Stellaria media (L.) Vill., Trifolium sp., Capsella bursa-pastoris (L.) Medik. Regarding the permission of marketing of composts, the related examinations, and their evaluations, the Hungarian regulation (Licensing, storage, distribution, and utilization of crop increasing materials 36/2006. (V. 18.) FVM Regulation) states that the compost that is to be sold as a product cannot contain quarantine weed seeds or plant parts. These weeds are the following: Ambrosia artemisiifolia L., Solanum dulcamara L., Asclepias syriaca L., and Cuscuta sp.

Based on the results of our examinations, it can be concluded that there was not any weed species considered as quarantine weed in the case of the backyard nor of the ecological composts. However, based on the results, it can be observed that among all the examined composts, only the compost B did not contain viable weed seeds, based on the required test. Regarding the other examined composts, it can be stated that in some cases (e.g., backyard compost C), if they are applied to the field, they could cause serious weed problems due to the emerging weeds on the compost treated fields. In the European countries, there is not any unified regulation related to the weed seed dispersal effects of composts. For example, in Italy and France, there is not any regulation for this; in Belgium and Great Britain, however, the high-quality compost must be free of viable weed seeds. In the case of Germany and the Netherlands, the allowed limit of viable weed seeds is two, while in Austria this value reaches three viable weed seeds per one liter of compost sample in its original state [49]. During examinations in general, the compost samples are mixed with some other material, or medium, then the mixture is watered and stored in regulated climatic conditions with available light. After the examination period, the number of emerged weeds is determined. This is in contrast to the Austrian standard method wherein the samples need to be mixed with high-quality peat kept moist, and, after 15 days of examination, the number of emerged weeds determined per litre of compost [62]. However, the standard method that was applied regarding the setting of the mixture and the length of examination time can be considered unique. Based on the obtained results, and considering the smaller amount of compost weight $(100 \mathrm{~g})$ as a basis, it can be assumed that the quality of all the examined compost samples (except for compost B) does not reach the required limit of the above-mentioned countries. This means that the quality of these composts was objectionable in terms of weed seed dispersal effect. This also draws attention to the fact that, during inappropriate backyard composting, the weed seeds do not lose their germination ability at the end of the process [50].

\subsection{Potentially Toxic Element Content}

Based on the results of the examined parameters, the potentially toxic element content of the samples is shown on Table 2.

Based on the presented results, it can be stated that all the examined backyard and ecological composts met the Hungarian requirements for the potentially toxic elements. However, the copper concentration ( $98.16 \mathrm{mg} \times \mathrm{kg}^{-1} \mathrm{~d}$.m.) of backyard compost $\mathrm{K}$ was close to the limit value $\left(100 \mathrm{mg} \times \mathrm{kg}^{-1} \mathrm{~d}\right.$.m.) The reason for the relatively high copper content of backyard compost $\mathrm{K}$ can be partially explained by the applied raw materials and the applied dishwashing water, which was only used in this case, for moistening compost. Fernández-Delgado Juárez et al. (2015) also noticed high copper content in their research in the case of green waste composts [63]. It can be further stated that the backyard composts only partially met the requirements of the EU regarding the potentially toxic elements and the regulations for the backyard composts (e.g., Austria, hobby gardening, EU Ecolabel). Backyard compost $\mathrm{K}$ did not meet the requirements of some regulations (Germany, biowaste ordinance, Class I, limit value 70, measured value $98.16 \mathrm{mg} \times \mathrm{kg}^{-1}$ 
d.m.) As explained earlier, the high copper content of compost $K$, similarly to the high cadmium content, can be explained by the applied dishwashing water. In the case of backyard compost $\mathrm{F}$, the higher $\mathrm{Cd}$ content can be explained by the wood ash since it may have contained high amounts of $\mathrm{Cd}\left(2.3 \mathrm{mg} \times \mathrm{kg}^{-1} \mathrm{~d}\right.$.m.) [63]. Based on the results, it can be emphasized that the potentially toxic element content of the examined composts, which originated from and was utilized in ecological farms, met the specific requirements (Austria, organic farming, EU Regulation on organic agriculture) for composts that can be utilized in ecological farms. All of the examined ecological composts resulted in lower potentially toxic element content and narrower concentration range compared with the backyard composts.

Table 2. The determined potentially toxic element content of the examined composts.

\begin{tabular}{|c|c|c|c|c|c|c|c|}
\hline \multirow{2}{*}{ Sample } & $\mathrm{Cd}$ & $\mathrm{Cr}$ & $\mathrm{Cu}$ & $\mathrm{Hg}$ & $\mathbf{N i}$ & $\mathrm{Pb}$ & $\mathrm{Zn}$ \\
\hline & \multicolumn{7}{|c|}{$\mathrm{mg} \times \mathrm{kg}^{-1}$ d.m. } \\
\hline $\mathrm{A}^{\mathrm{a}}$ & $0.23 \pm 0.03$ & $10.68 \pm 0.00$ & $12.25 \pm 0.11$ & nd & $5.12 \pm 0.06$ & $3.49 \pm 0.12$ & $49.8 \pm 0.3$ \\
\hline $\mathrm{B}^{\mathrm{a}}$ & $0.64 \pm 0.03$ & $17.42 \pm 0.03$ & $29.05 \pm 0.28$ & nd & $7.95 \pm 0.29$ & $15.21 \pm 0.70$ & $94.8 \pm 0.1$ \\
\hline $\mathrm{C}^{\mathrm{a}}$ & $0.69 \pm 0.05$ & $16.51 \pm 0.12$ & $32.00 \pm 0.12$ & nd & $9.35 \pm 0.24$ & $11.80 \pm 0.22$ & $118.7 \pm 0.1$ \\
\hline $\mathrm{D}^{\mathrm{a}}$ & $0.35 \pm 0.01$ & $12.28 \pm 0.07$ & $19.16 \pm 0.60$ & nd & $5.87 \pm 0.27$ & $5.30 \pm 0.57$ & $66.5 \pm 0.3$ \\
\hline $\mathrm{E}^{\mathrm{a}}$ & $0.85 \pm 0.01$ & $22.87 \pm 0.29$ & $23.35 \pm 0.27$ & nd & $10.06 \pm 0.18$ & $18.68 \pm 0.49$ & $134.8 \pm 0.9$ \\
\hline $\mathrm{F}^{\mathrm{a}}$ & $0.93 \pm 0.05$ & $30.02 \pm 0.31$ & $21.07 \pm 0.39$ & nd & $10.84 \pm 0.1$ & $14.17 \pm 0.62$ & $109.2 \pm 0.2$ \\
\hline $\mathrm{G}^{\mathrm{a}}$ & $0.87 \pm 0.01$ & $20.59 \pm 0.19$ & $11.81 \pm 0.29$ & nd & $8.66 \pm 0.21$ & $15.55 \pm 0.33$ & $52.7 \pm 0.0$ \\
\hline $\mathrm{H}^{\mathrm{a}}$ & $0.77 \pm 0.03$ & $11.14 \pm 0.02$ & $9.82 \pm 0.08$ & nd & $6.35 \pm 0.63$ & $6.56 \pm 0.40$ & $85.7 \pm 0.7$ \\
\hline $\mathrm{I}^{\mathrm{a}}$ & $0.66 \pm 0.04$ & $17.87 \pm 0.02$ & $44.03 \pm 0.52$ & nd & $11.76 \pm 0.15$ & $9.21 \pm 0.41$ & $53.8 \pm 0.3$ \\
\hline $\mathrm{J}^{\mathrm{a}}$ & $0.65 \pm 0.01$ & $15.11 \pm 0.15$ & $25.08 \pm 0.47$ & nd & $9.74 \pm 0.01$ & $8.53 \pm 0.97$ & $55.6 \pm 0.3$ \\
\hline $\mathrm{K}^{\mathrm{a}}$ & $0.91 \pm 0.06$ & $29.19 \pm 0.46$ & $98.16 \pm 2.87$ & nd & $7.91 \pm 0.20$ & $13.70 \pm 1.06$ & $78.9 \pm 0.4$ \\
\hline $\mathrm{L}^{\mathrm{a}}$ & $0.56 \pm 0.03$ & $10.45 \pm 0.01$ & $22.12 \pm 0.16$ & nd & $5.64 \pm 0.44$ & $12.12 \pm 0.08$ & $135.6 \pm 0.1$ \\
\hline $\mathrm{M}^{\mathrm{a}}$ & $0.70 \pm 0.11$ & $17.04 \pm 0.11$ & $21.74 \pm 0.49$ & nd & $10.21 \pm 0.14$ & $10.14 \pm 0.12$ & $71.2 \pm 0.3$ \\
\hline $\mathrm{N}^{\mathrm{b}}$ & nd & $11.1 \pm 0.06$ & $10.07 \pm 0.39$ & nd & $5.13 \pm 0.15$ & $5.6 \pm 0.02$ & $38.8 \pm 0.5$ \\
\hline $\mathrm{O}^{\mathrm{b}}$ & nd & $13.46 \pm 0.24$ & $12.85 \pm 0.44$ & nd & $5.28 \pm 0.14$ & $6.02 \pm 0.2$ & $46.6 \pm 0.7$ \\
\hline $\mathrm{P}^{\mathrm{b}}$ & nd & $13.42 \pm 0.25$ & $10.13 \pm 0.53$ & nd & $5.69 \pm 0.13$ & $5.39 \pm 0.63$ & $32.9 \pm 0.7$ \\
\hline
\end{tabular}

a backyard compost; ${ }^{\mathrm{b}}$ composts from ecological farms; d.m.-dry matter; nd-not detectable.

\subsection{Macro and Micronutrient Content}

Based on the results, the macronutrient and micronutrient content of the backyard and the ecological composts typically did not differ from each other, and were in the same range. It can be stated that all the examined backyard and ecological composts met the requirements valid in Hungary for the calcium content; however, only some of the backyard composts met the requirements for the magnesium content (composts B, C, D, H, and M). Therefore, the examined composts mixed into the topsoil in a suitable quantity would provide an appropriate amount of calcium and sufficient amount of magnesium for the produced crops. Based on the macro and micronutrient content of the examined composts, it can be stated that their calcium (1.32-5 and $1.8-3.9 \%$ d.m.) and magnesium content (0.3-0.7 and $0.3-0.4 \%$ d.m.) reached and exceeded the typical range for cow manures (calcium: 2.03-2.16; magnesium: $0.42-0.46 \%$ d.m.) that is often applied in hobby gardens and household farming, which is a common application area for backyard composts. Their iron (0.6-1.1 and 0.7\% d.m.) and manganese (239-667 and 296-340 $\mathrm{mg} \times \mathrm{kg}^{-1} \mathrm{~d}$ d.m.) content, however, exceeded the typical range for cow manures (iron: $0.22-0.51 \%$ d.m.; manganese: $117-161 \mathrm{mg} \times \mathrm{kg}^{-1} \mathrm{~d}$.m.) [64]. Based on these findings, it can be concluded that, according to the determined macronutrient $(\mathrm{Ca}, \mathrm{Mg})$ and micronutrient $(\mathrm{Fe}, \mathrm{Mn})$ content of the examined composts, they have similar and, in some cases, more favorable nutrient-supplying capacity in crop production than the frequently-used cow manures. 


\subsection{Results of Statistical Analysis}

The possible effect of the most common treatments on the potential toxic elements and macro and micronutrient content was examined. The grouping of the samples according to the treatments was as follows:

1 = Monthly turning, MT (Samples A, B, H)

$2=$ Monthly turning, moistening, MTM (Samples C, D)

$3=$ No treatment, NT (Samples E, F, K, L)

$4=$ Addition of earthworms (not red worms), AE (Samples G, J, M)

$5=$ Periodic turning, addition of earthworms, PAE (Sample I)

6 = Periodic turning, moistening, PTM (Samples N, O, P)

The variance of homogeneity and significant differences in category means are present simultaneously only for $\mathrm{Zn}$ and $\mathrm{Mg}$ : zinc as a potential toxic element, and magnesium as a macronutrient. A post hoc test could not be performed because treatment 5 (periodic turning and addition of earthworms) had only one element. As there was no post hoc test, the visual representation of the means provides a basis for judging differences between groups.

It can be seen from Figure 2 that the largest difference is between treatments 3 and 6 in terms of $\mathrm{Zn}$ content.

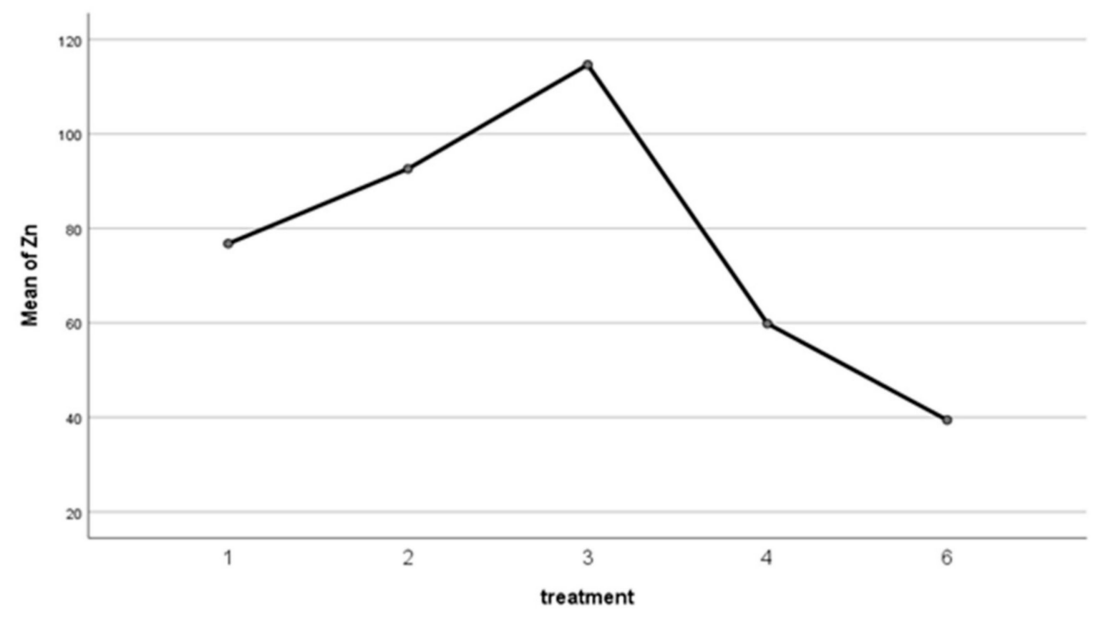

Figure 2. Average comparison. Note: unit of measure is $\mathrm{mg} \times \mathrm{kg}^{-1} \mathrm{~d} . \mathrm{m}$.

In terms of the effect on $\mathrm{Mg}$ content, there was the largest difference between treatments 2 and 3 that can be seen in Figure 3.

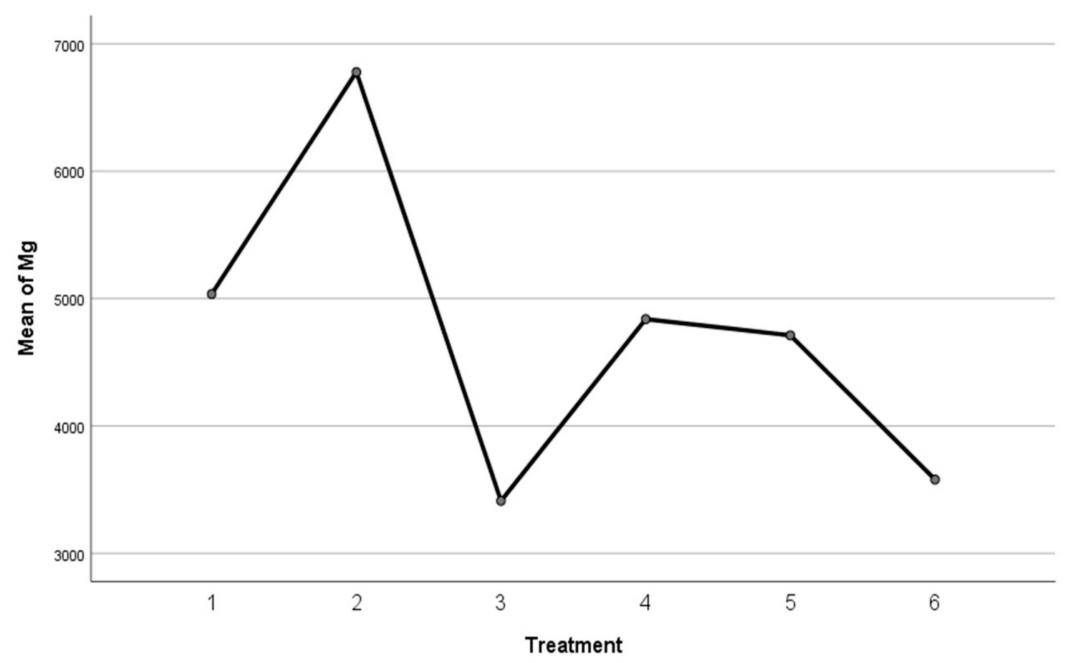

Figure 3. Average comparison of $\mathrm{Mg}$. Note: unit of measure is $\mathrm{mg} \times \mathrm{kg}^{-1} \mathrm{~d} . \mathrm{m}$. 
In the cases wherein no treatment was applied, the Mg content was at the lowest level, while the zinc content, which is a potentially toxic element, was the highest. The latter was true even for lead, cadmium, and chromium. In the case of the untreated compost, however, the Ca content was at the lowest level. The effects of the raw materials on toxic element content and macro and microelement content were also examined. The ingredients of the raw materials of the examined composts were very diverse. In order to compare the samples, five categories were created, taking into account the chemical properties of the ingredients and their main components' effect on the microbial activity. Components that have a differentiating effect on the quality parameters of the composts, such as the effect on the toxic element and macro- and micronutrient content, were selected. According to this, the following categories were created:

1 = GGW-garden green waste only (Samples A, B, J)

2 = M-Use of manure (Samples H, L, P)

$3=$ S-Use of soil and wood ash (Samples E, F)

$4=$ WL-Walnut leaves (Samples N, O)

$5=$ GGW and others (Samples C, D, G, I, K, M)

Category averages differed significantly for $\mathrm{Cd}, \mathrm{Cr}, \mathrm{Ni}$, and $\mathrm{Fe}$. The post hoc (Scheffe) test was feasible in this case and showed a significant difference between raw material categories 3 and 4 (Figure 4). Thus, cadmium levels were highest in terrestrial raw materials, while they were lowest in walnut leaves. The latter includes the fact that the walnut leaf was of organic origin.

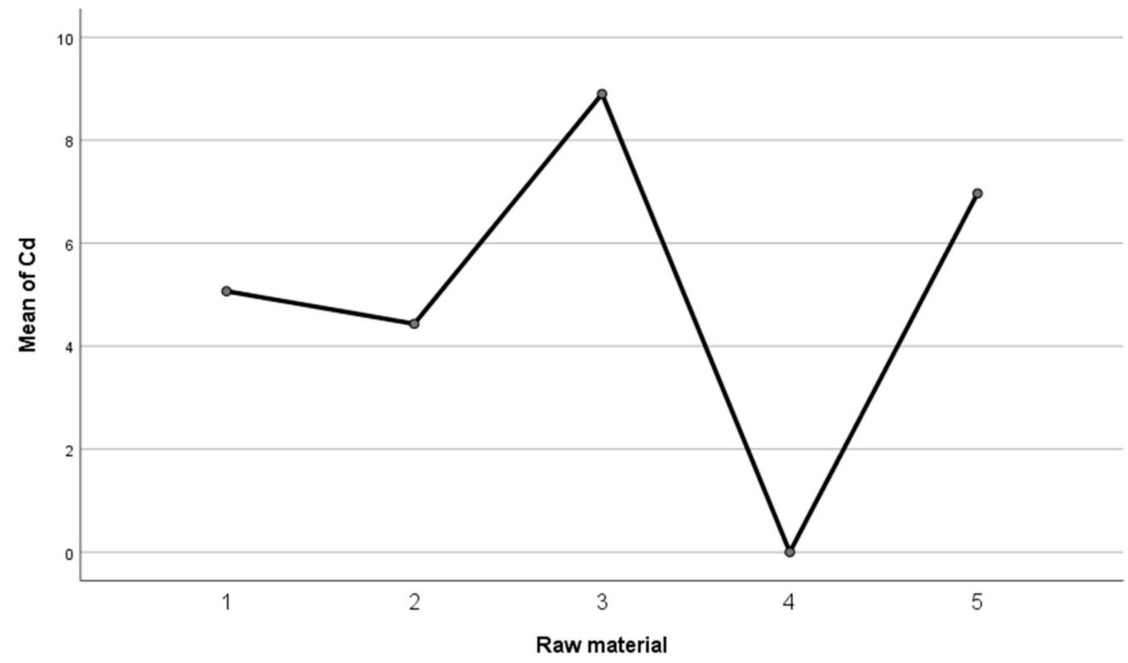

Figure 4. Average comparison for $\mathrm{Cd}$.

The raw material had an effect on the level of the $\mathrm{Cd}$ (Figure 4). Category averages differed significantly for cadmium and iron when we analyzed the impact of the two main raw material categories, ecological and conventional. A post hoc test could not be performed here either, as the number of categories (organic and conventional raw material) was less than three. Overall, based on the impact assessments of the previous two raw materials, it can be stated that the use of organic raw materials (since walnut leaves were also organic) had a positive effect on the overall quality of the compost, including the cadmium level [65-67]. In addition to the abovementioned, the effects of composting time, method, treatment, and raw materials were also examined on other quality characteristics of compost, i.e., AT4 and weed content, but no significant correlation was found, probably due to the low number of items in the sample [68]. Nevertheless, the study is unique because there has never been such a detailed, multi-characteristic compost study in Hungary.

\subsection{Practical Implication of the Study}

The results of this complex study highlight the uncertainties regarding the quality of backyard compost. The unfavorable macro and micronutrient content and the possible 
weeding effect do not pose a risk if compost remains within the farm cycle; its use is highly recommended to support circular systems. It is only necessary to comply with the regulations if, in addition to its backyard-level use, the compost is sold. Furthermore, composting requires expertise and attention if nutrient replenishment is provided over a larger area (small scale farm level) with backyard compost. In this case, it is worth taking into account the recommendations supported by the literature (separate collection of weeds, regular turning and watering). Due to the essence of backyard composting, each compost producer uses their own raw materials, ensuring the closed backyard nutrient cycle and the regulation of external outputs. However, this implies the difficulties of preparing a comparative analysis and taking uniform samples. Apart from the raw materials of backyard composting, the applied composting processes, the frequency of the processes, and the quality of their execution are not regulated; these factors are greatly influenced by the expertise of the compost maker. Further analyses and additional samples from organic farms are also needed to draw deeper, statistically verifiable conclusions.

\section{Discussion}

\subsection{Maturity and Stability}

Based on the results of the examination, it can be stated that the composts produced in the backyard and organic farms are characterized by different quality in terms of maturity and stability values. It should be added that the collected samples were considered mature and ready to use by the compost makers themselves, regardless of the age of the compost (e.g., samples $\mathrm{N}$ and $\mathrm{O}$ were 8 months old whilst samples $\mathrm{L}$ and $\mathrm{M}$ were 4 years old). However, in most cases at a household level and small farms, the analysis of the maturity and readiness of the final product is performed by empirical tests based on the compost maker's senses and experience, or lack thereof. Physical characteristics such as texture, smell, or color are the major indicators, rather than laboratory tests, rendering it a challenge to have consistent and accurate results at all times [69]. Consequently, if the compost does not achieve optimal levels of maturity and stability, it could slow down the plant growth process and therefore be considered of inferior quality compared with store-bought compost [70]. For this reason, education on basic practices and standards of compost making to enthusiast backyard gardeners and small-scale bio farmers is highly suggested to achieve desirable performance and usability of compost.

\subsection{Toxicity and Macro and Micro Nutrients}

The quality properties of the analyzed composts were greatly influenced by the different techniques and raw materials used. The levels of toxicity and the content of macro and micro nutrients identified in all the samples fell within the Hungarian parameters for quality and safe compost. Moreover, the determined macronutrient $(\mathrm{Ca}, \mathrm{Mg})$ and micronutrient $(\mathrm{Fe}, \mathrm{Mn})$ content of the examined composts have similar and, in some cases, more favorable nutrient-supplying capacity in crop production than the frequently used cow manure-based composts. Despite the positive results, it is important to highlight the higher levels of zinc that fell close to the limit of toxicity and the low presence of magnesium, the latter being an important component in a high-quality compost. This tendency was found in samples with no treatments such as turning and watering, which would have sped up the composting process. The statistical analysis of our examinations, in part, supports Jakubus' results [25], according to which the initial raw materials of composts primarily determined their macro and microelement content and thus the quality of the finished compost. This is evidenced by the fact that in the case of untreated compost, wherein the initial raw materials included the slowly degradable sycamore and grape leaves, not enough magnesium was revealed even after 3-4 years without intervention. This can be explained in part by the low magnesium content of the initial raw materials, but also by the lack of composting treatments that slowed down the mineralization. Similarly, the higher zinc content in the non-treated composts can be explained by the initial raw materials (wood and ash, which can be even higher in the case of preservative-treated 
wood or surface-treated wood waste), which occurred mainly in compost samples with no treatments. Another important consideration is regarding the higher levels of cadmium content, mainly in samples that contained wood ash (samples E and F), dishwashing water (sample K), and/or kitchen waste as raw materials. This examination confirms what other authors have already described [65]: that the release of cadmium into soil and groundwater is largely attributed to anthropogenic activities, including the use of synthetic phosphorus fertilizers (which may be contaminated with cadmium depending on the location of extraction). Other potential sources of the cadmium pollution identified in the literature are drinking water and recycled wastewater [66,67]. Given the above, samples from organic farming resulted in zero cadmium content.

\subsection{Seed Content}

Regarding the weed-seed content and germination test, it can be stated that the weed-seeds species emerging from the compost samples analysed are not considered as quarantine weeds by Hungarian regulations in the case of the backyard or the ecological compost samples. It is highly advised, for backyard compost especially, to avoid the use of weeds as raw materials in the compost pile at a flowering or seed stage because the recognition of weeds and the identification of their lifeform (in order to apply e.g., pre-drying in the case of weeds with propagating roots) present a great challenge for inexperienced farmers/gardeners, as evidenced by sample B wherein no germinated weed seed was detected. In addition, knowledge regarding the raw compost materials and their behaviour during the composting process is essential since no weed was included in the raw materials. In both backyard farming and organic farming, the sorting of seeded weeds is a timeconsuming activity during manual weeding. In the case of annual weeds, their prolonged seed maturation period must also be considered, as supported by other studies [70]. These findings are confirmed by the weed-test results performed in this study. However, with appropriate composting practices, excessive weed emergence can be avoided. Furthermore, knowledge of composting, especially regarding the proper preparation of weeds as ingredients, the recognition of the importance of the thermodynamics of the pile, and the role of turning the compost, is essential. It should be noted that weed germination was not prominent in the case of samples from organic farming. Interestingly, germinated weed was also observed in the case of compost which consisted of $100 \%$ walnut leaves; this can be explained by the method of collection of walnut leaves from the soil and by the random propagation of seeds due to wind.

\section{Conclusions}

Kitchen and backyard waste represent a high cost to municipal waste collection systems. The quality analysis of backyard compost and compost from ecological farms proves that using simple methods nets positive outcomes at a macro and micro level of nutrients and limits the toxicity of backyard composting. Although, in addition to the safe usage of compost, it would be worthwhile to examine the effect of compost in terms of crop yield and nutrient and soil organic matter balance at the small-farm level with a special regard to the whole nutrient cycle of organic farms wherein compost can be a valuable resource to organic fertilizers. At a household and community level, municipalities have the potential to encourage composting with a plan of basic education on composting. It is particularly important to note that for the sampled compost households, the composting process is not waste treatment, but rather the return of organic matter, providing nutrient cycling, and is therefore part of value creation. Households have also taken extra care throughout their consumption systems to ensure that contaminated or risky foods do not enter the kitchen or into the compost and retail gardens. Backyard and biofarm composts have acceptable quality and safety to be utilized by their own producers without the need of external or mechanized processes. In general, the circulation of organic matter can be increased with the spread of home composting. Measures dealing with the treatment of biowaste from mixed municipal waste can create major contributions 
to its dissemination in practice through concrete actions such as the introduction of a new collection system, further reduction of the amount of biodegradable waste sent to landfills, and the promotion of community based composting. It is no coincidence that the Food Systems Summit 2021 addresses food waste problems as a priority and influences the National Waste Management Plans for a Circular Economy, which clearly supports the promotion of home and community composting and translates policy measures into actions. However, local governments are also encouraged to create programs and foster circular investment to diversify the systems intended to reduce the ecological and economic impacts of conventional waste collection.

Author Contributions: All authors: conceived the study, involved in its design, and participated in field data collection. A.B., L.A., K.P., A.U.: prepared the data, performed the statistical analysis. A.U., K.P., C.F., F.R.D. drafted the manuscript together. C.F., C.G., F.R.D., A.U. read and commented on the first draft. All authors have read and agreed to the published version of the manuscript.

Funding: This research was funded by Hungarian National Research, Development and Innovation Office-NKFIH (Program ID: OTKA 131925) and KTIA_AIK 121 2013-0015 programs.

Institutional Review Board Statement: Not applicable.

Informed Consent Statement: Not applicable.

Data Availability Statement: Not applicable.

Conflicts of Interest: The authors declare no conflict of interest.

Limitations: The study environment was specifically in a small urban setting, where residential areas are surrounded by greenery and typically supplement their fruit and vegetable needs with food production for their own consumption. In the study areas, pollution indicators related to environmental elements are not relevant.

\section{References}

1. Fogarassy, C.; Finger, D. Theoretical and Practical Approaches of Circular Economy for Business Models and Technological Solutions. Resources 2020, 9, 76. [CrossRef]

2. European Comission COM. Communication from the Commission to the European Parliament, the Council, the European Economic and Social Committee and the Committee of the Region. Toward A Circular Economy: Zero Waste Programme for Europe; European Comission: Brussels, Belgium, 2014.

3. Blumenthal, K. Generation and Treatment of Municipal Waste. Available online: https:/ /ec.europa.eu/eurostat/documents/34 33488/5579064/KS-SF-11-031-EN.PDF/00c0b3fe-db08-4076-b39a-e92015ce99e0 (accessed on 12 May 2021).

4. Alexa, L.; Dér, S. Szakszerü Komposztálás Elmélet És Gyakorlat; Profikomp Kft.: Budapest, Hungary, 2001; ISBN 978-963-00-5809-4.

5. Lleó, T.; Albacete, E.; Barrena, R.; Font, X.; Artola, A.; Sánchez, A. Home and Vermicomposting as Sustainable Options for Biowaste Management. J. Clean. Prod. 2013, 47, 70-76. [CrossRef]

6. Toledo, M.; Siles, J.A.; Gutiérrez, M.C.; Martín, M.A. Monitoring of the Composting Process of Different Agroindustrial Waste: Influence of the Operational Variables on the Odorous Impact. Waste Manag. 2018, 76, 266-274. [CrossRef]

7. Palaniveloo, K.; Amran, M.A.; Norhashim, N.A.; Mohamad-Fauzi, N.; Peng-Hui, F.; Hui-Wen, L.; Kai-Lin, Y.; Jiale, L.; Chian-Yee, M.G.; Jing-Yi, L.; et al. Food Waste Composting and Microbial Community Structure Profiling. Processes 2020, 8, 723. [CrossRef]

8. Bermudez, J.F.; Saldarriaga, J.F.; Osma, J.F. Portable and Low-Cost Respirometric Microsystem for the Static and Dynamic Respirometry Monitoring of Compost. Sensors 2019, 19, 4132. [CrossRef] [PubMed]

9. Gu, W.; Zhang, F.; Xu, P.; Tang, S.; Xie, K.; Huang, X.; Huang, Q. Effects of Sulphur and Thiobacillus Thioparus on Cow Manure Aerobic Composting. Bioresour. Technol. 2011, 102, 6529-6535. [CrossRef]

10. Deepesh, V.; Verma, V.K.; Suma, K.; Ajay, S.; Gnanavelu, A.; Madhusudanan, M. Evaluation of an Organic Soil Amendment Generated from Municipal Solid Waste Seeded with Activated Sewage Sludge. J. Mater. Cycles Waste Manag. 2016, 18 , $273-286$. [CrossRef]

11. Cai, Q.-Y.; Mo, C.-H.; Wu, Q.-T.; Zeng, Q.-Y.; Katsoyiannis, A. Concentration and Speciation of Heavy Metals in Six Different Sewage Sludge-Composts. J. Hazard. Mater. 2007, 147, 1063-1072. [CrossRef]

12. Bai, J.; Shen, H.; Dong, S. Study on Eco-Utilization and Treatments of Highway Greening Waste. Procedia Environ. Sci. 2010, 2, 25-31. [CrossRef]

13. Yu, H.; Xie, B.; Khan, R.; Shen, G. The Changes in Carbon, Nitrogen Components and Humic Substances during Organic-Inorganic Aerobic Co-Composting. Bioresour. Technol. 2019, 271, 228-235. [CrossRef]

14. Cooperband, L.R. Composting: Art and Science of Organic Waste Conversion to a Valuable Soil Resource. Lab. Med. 2000, 31, 283-290. [CrossRef] 
15. Dunst, G. Kompostierung; Leopold Stocker Verlag: Graz-Stuttgart, Austria, 1991.

16. Gottschall, R. Kompostierung: Optimale Aufbereitung und Verwendung Organischer Materialien im Ökologischen Landbau; Alternative Konzepte; 4. Aufl; Müller: Karlsruhe, Germany, 1990; ISBN 978-3-7880-9798-1.

17. Roulac, J.W. Backyard Composting; Green Earth Books: Totnes, UK, 1996; ISBN 978-1-900322-04-1.

18. Andersen, J.K.; Boldrin, A.; Christensen, T.H.; Scheutz, C. Mass Balances and Life Cycle Inventory of Home Composting of Organic Waste. Waste Manag. 2011, 31, 1934-1942. [CrossRef]

19. Jasim, S.; Smith, S.R. The Practicability of Home Composting for the Management of Biodegradable Domestic Solid Waste. Ph.D. Thesis, Imperial College London, London, UK, 2003.

20. Colón, J.; Martínez-Blanco, J.; Gabarrell, X.; Artola, A.; Sánchez, A.; Rieradevall, J.; Font, X. Environmental Assessment of Home Composting. Resour. Conserv. Recycl. 2010, 54, 893-904. [CrossRef]

21. Martínez-Blanco, J.; Colón, J.; Gabarrell, X.; Font, X.; Sánchez, A.; Artola, A.; Rieradevall, J. The Use of Life Cycle Assessment for the Comparison of Biowaste Composting at Home and Full Scale. Waste Manag. 2010, 30, 983-994. [CrossRef]

22. Papadopoulos, A.E.; Stylianou, M.A.; Michalopoulos, C.P.; Moustakas, K.G.; Hapeshis, K.M.; Vogiatzidaki, E.E.I.; Loizidou, M.D. Performance of a New Household Composter during In-Home Testing. Waste Manag. 2009, 29, 204-213. [CrossRef]

23. Gómez, R.B.; Lima, F.V.; Ferrer, A.S. The Use of Respiration Indices in the Composting Process: A Review. Waste Manag. Res. 2006, 24, 37-47. [CrossRef] [PubMed]

24. Fricke, K.; Vogtmann, H. Compost Quality: Physical Characteristics, Nutrient Content, Heavy Metals and Organic Chemicals. Toxicol. Environ. Chem. 1994, 43, 95-114. [CrossRef]

25. Jakubus, M.A. Comparative Study of Composts Prepared from Various Organic Wastes Based on Biological and Chemical Parameters. Agronomy 2020, 10, 869. [CrossRef]

26. Hunyadi, G. Hulladékból Előállított Komposztok Degradációs Folyamatainak Nyomon Követése. Analyze of the Degradation Process of Waste Compost. Ph.D. Thesis, University of Debrecen, Debrecen, Hungary, 2012.

27. Mathur, S.P.; Owen, G.; Dinel, H.; Schnitzer, M. Determination of Compost Biomaturity. I. Literature Review. Biol. Agric. Hortic. 1993, 10, 65-85. [CrossRef]

28. López, M.; Huerta-Pujol, O.; Martínez-Farré, F.X.; Soliva, M. Approaching Compost Stability from Klason Lignin Modified Method: Chemical Stability Degree for OM and N Quality Assessment. Resour. Conserv. Recycl. 2010, 55, 171-181. [CrossRef]

29. Mushtaq, M.; Iqbal, M.K.; Khalid, A.; Khan, R.A. Humification of Poultry Waste and Rice Husk Using Additives and Its Application. Int. J. Recycl. Org. Waste Agric. 2019, 8, 15-22. [CrossRef]

30. Zhang, L.; Sun, X. Evaluation of Maifanite and Silage as Amendments for Green Waste Composting. Waste Manag. 2018, 77, 435-446. [CrossRef]

31. Kebrom, T.H.; Woldesenbet, S.; Bayabil, H.K.; Garcia, M.; Gao, M.; Ampim, P.; Awal, R.; Fares, A. Evaluation of Phytotoxicity of Three Organic Amendments to Collard Greens Using the Seed Germination Bioassay. Environ. Sci. Pollut. Res. 2019, 26, 5454-5462. [CrossRef] [PubMed]

32. Morel, T.L.; Colin, F.; Germon, J.C. Methods for the Evaluation of the Maturity of Municipal Refuse Compost. In Composting of Agriculture and Other Wastes; Elsevier Applied Science Publishers: London, UK, 1985; pp. 56-72.

33. Jímenez, E.I.; Garcia, V.P. Evaluation of City Refuse Compost Maturity: A Review. Biol. Wastes 1989, 27, 115-142. [CrossRef]

34. Bari, Q.H.; Koenig, A. Effect of Air Recirculation and Reuse on Composting of Organic Solid Waste. Resour. Conserv. Recycl. 2001, 33, 93-111. [CrossRef]

35. Cerda, A.; Artola, A.; Font, X.; Barrena, R.; Gea, T.; Sánchez, A. Composting of Food Wastes: Status and Challenges. Bioresour. Technol. 2018, 248, 57-67. [CrossRef]

36. Scoton, E.J.; Battistelle, R.A.G.; Bezerra, B.S.; Akutsu, J. A Sewage Sludge Co-Composting Process Using Respirometric Monitoring Method in Hermetic Rotary Reactor. J. Clean. Prod. 2016, 121, 169-175. [CrossRef]

37. du Plessis, C.A.; Barnard, P.; Naldrett, K.; de Kock, S.H. Development of Respirometry Methods to Assess the Microbial Activity of Thermophilic Bioleaching Archaea. J. Microbiol. Methods 2001, 47, 189-198. [CrossRef]

38. Adani, F.; Gigliotti, G.; Valentini, F.; Laraia, R. Respiration Index Determination: A Comparative Study of Different Methods. Compost Sci. Util. 2003, 11, 144-151. [CrossRef]

39. Sánchez Arias, V.; Fernández, F.J.; Rodríguez, L.; Villaseñor, J. Respiration Indices and Stability Measurements of Compost through Electrolytic Respirometry. J. Environ. Manage. 2012, 95, S134-S138. [CrossRef]

40. Binner, E.; Zach, A. Laboratory tests describing the biological reactivity of pretreated residual wastes. In Bidlingmaier; deBertoldi, M., Diaz, L., Papadimitriou, E., Eds.; Organic Recovery and Biological Treatment; Rhombos-Verlag-ORBIT 99.: Weimar, Germany, 1999; pp. 255-261.

41. Lasaridi, K.E.; Stentiford, E.I. A Simple Respirometric Technique for Assessing Compost Stabilit y. Water Res. 1998, 32, $3717-3723$. [CrossRef]

42. Abdi, L.; Molaee Aghaee, E.; Nazmara, S.; reza Alipour, M.; Fakhri, Y.; Mousavi Khaneghah, A. Potentially Toxic Elements (PTEs) in Corn (Zea mays) and Soybean (Glycine max) Samples Collected from Tehran, Iran: A Health Risk Assessment Study. Int. J. Environ. Anal. Chem. 2020, 1-12. [CrossRef]

43. Retamal-Salgado, J.; Hirzel, J.; Walter, I.; Matus, I. Bioabsorption and Bioaccumulation of Cadmium in the Straw and Grain of Maize (Zea mays L.) in Growing Soils Contaminated with Cadmium in Different Environment. Int. J. Environ. Res. Public. Health 2017, 14, 1399. [CrossRef] [PubMed] 
44. Smedley, P.L.; Kinniburgh, D.G. A Review of the Source, Behaviour and Distribution of Arsenic in Natural Waters. Appl. Geochem. 2002, 17, 517-568. [CrossRef]

45. Rahman, M.A.; Hasegawa, H. High Levels of Inorganic Arsenic in Rice in Areas Where Arsenic-Contaminated Water Is Used for Irrigation and Cooking. Sci. Total Environ. 2011, 409, 4645-4655. [CrossRef]

46. Hajeb, P.; Sloth, J.J.; Shakibazadeh, S.; Mahyudin, N.A.; Afsah-Hejri, L. Toxic Elements in Food: Occurrence, Binding, and Reduction Approaches: Toxic Elements in Food. Compr. Rev. Food Sci. Food Saf. 2014, 13, 457-472. [CrossRef]

47. Picariello, E.; Baldantoni, D.; Izzo, F.; Langella, A.; De Nicola, F. Soil Organic Matter Stability and Microbial Community in Relation to Different Plant Cover: A Focus on Forests Characterizing Mediterranean Area. Appl. Soil Ecol. 2021, $162,103897$. [CrossRef]

48. Petruzzelli, G. Heavy Metals in Compost and their Effect on Soil Quality. In The Science of Composting; de Bertoldi, M., Sequi, P., Lemmes, B., Papi, T., Eds.; Springer: Dordrecht, The Netherlands, 1996; pp. 213-223. ISBN 978-94-010-7201-4.

49. Saveyn, H.; Eder, P. End-of-Waste Criteria for Biodegradable Waste Subjected to Biological Treatment (Compost E Digestate): Technical Proposals; Publications Office: Luxembourg, 2014.

50. Idelmann, M. Hygienisierung Von Kompost: Möglichkeiten Zum Nachweis Einer Erfolgreichen Abtötung Von Pathogenen Und Unkrautsamen; Dissertation, Schriftenreihe des Fachgebietes Abfalltechnik/Universität Kassel Dissertationen; Univ. Press: Kassel, Germany, 2006; ISBN 978-3-89958-203-1.

51. Dahlquist, R.M.; Prather, T.S.; Stapleton, J.J. Time and Temperature Requirements for Weed Seed Thermal Death. Weed Sci. 2007, 55, 619-625. [CrossRef]

52. Egley, G.H. High-Temperature Effects on Germination and Survival of Weed Seeds in Soil. Weed Sci. 1990, 38, 429-435. [CrossRef]

53. Eghball, B.; Lesoing, G.W. Viability of Weed Seeds Following Manure Windrow Composting. Compost Sci. Util. 2000, 8, 46-53. [CrossRef]

54. Wiese, A.F.; Sweeten, J.M.; Bean, B.W.; Salisbury, C.D.; Chenault, E.W. High Temperature Composting of Cattle Feedlot Manure Kills Weed Seed. Appl. Eng. Agric. 1998, 14, 377-380. [CrossRef]

55. ÖNORM S 2027-4: Evalution of Waste from Mechanical-Biological Treatment-Part 4: Stability Parameters-Respiration Activity (AT4); Association of Germany: Berlin, Germany, 2012.

56. MSZE 21420-18:2005: Hulladékok Jellemzése. A Nedvesség-És a Szárazanyag-Tartalom Meghatározása; Characterization of Wastes. Determination of Humidity and Dry Matter Content; Hungarian Standards Institution: Budapest, Hungary, 2005.

57. Bozym, M. Analytical Issues in the Assessment of Waste Stabilisation Degree after Biological Treatment. CHEMIK 2012, 66, 1211-1218.

58. MSZ-08-0012-4:1979: Tőzegek És Tőzegkészítmények Fizikai, Kémiai És Biológiai Vizsgálata. Gyomositó És Csírázásgátló Hatás Vizsgálata; Physical, Chemical and Biological Testing of Peat and Peat Products. Examination of Weed Expansion and Germ Killing Effect; Hungarian Standards Institution: Budapest, Hungary, 1979.

59. Kristanto, G.A.; Rahmah, S.A. Assessment of Compost Maturity Using The Static Respirometry Index. Reaktor 2019, 18, 194-201. [CrossRef]

60. Confesor, R.B.; Hamlet, J.M.; Shannon, R.D.; Graves, R.E. Potential Pollutants from Farm, Food and Yard Waste Composts at Differing Ages: Leaching Potential of Nutrients Under Column Experiments. Part II. Compost Sci. Util. 2009, 17, 6-17. [CrossRef]

61. Barrena, R.; Font, X.; Gabarrell, X.; Sánchez, A. Home Composting versus Industrial Composting: Influence of Composting System on Compost Quality with Focus on Compost Stability. Waste Manag. 2014, 34, 1109-1116. [CrossRef]

62. Jauch, M. Kompostieren-so Geht's: Müll Vermeiden, Kompost Sinnvoll Nutzen; Dem Kosmos-Rat vertrauen; Franckh-Kosmos: Stuttgart, Germany, 1996; ISBN 978-3-440-07096-3.

63. Scaglia, B.; Tambone, F.; Genevini, P.L.; Adani, F. Respiration Index Determination: Dynamic And Static Approaches. Compost Sci. Util. 2000, 8, 90-98. [CrossRef]

64. ÖNORM S 2023: Untersuchungsmethoden und Güteüberwachung von Komposten; Österreichisches Normungsinstitut: Vienna, Austria, 1993.

65. Fernández-Delgado Juárez, M.; Gómez-Brandón, M.; Insam, H. Merging Two Waste Streams, Wood Ash and Biowaste, Results in Improved Composting Process and End Products. Sci. Total Environ. 2015, 511, 91-100. [CrossRef]

66. Capar, S.G.; Tanner, J.T.; Friedman, M.H.; Boyer, K.W. Multielement Analysis of Animal Feed, Animal Wastes and Sewage Sludge. Environ. Sci. Technol. 1978, 12, 785-790. [CrossRef]

67. Kubier, A.; Pichler, T. Cadmium in Groundwater-A Synopsis Based on a Large Hydrogeochemical Data Set. Sci. Total Environ. 2019, 689, 831-842. [CrossRef]

68. Knappe, F.; Mohler, S.; Ostermayer, A.; Lazar, S.; Kaufmann, C. Comparative Evaluation of Substance Inputs Into Soils Via Different Input Paths; Federal Environmental Agency (Umweltbundesamt): Dessau-Roßlau, Germany, 2008.

69. López-Núñez, R.; Ajmal-Poley, F.; Burgos-Doménech, P. Prediction of As, Cd, Cr, Hg, Ni, and Se Concentrations in Organic Amendments Using Portable X-ray Fluorescence and Multivariate Modeling. Appl. Sci. 2020, 10, 5726. [CrossRef]

70. Weaver, S.E.; McWilliams, E.L. The Biology of Canadian Weeds.: 44. Amaranthus Retrojkxus L., A. Powellii S. Wats. and A. Hybridus L. Can. J. Plant Sci. 1980, 60, 1215-1234. 